Bilooka Yu., Fediv O., Stupnytska H., Bilookyi V., Bilookyi O., Rohovyi Y. The role of adipocytokines and endothelial dysfunction with irritable bowel syndrome associated with obesity. Journal of Education, Health and Sport. 2021;11(07): 219-227. eISSN 23918306. DOI http://dx.doi.org/10.12775/JEHS.2021.11.07.020

https://apcz.umk.pl/czasopisma/index.php/JEHS/article/view/JEHS.2021.11.07.020

https://zenodo.org/record/5156543

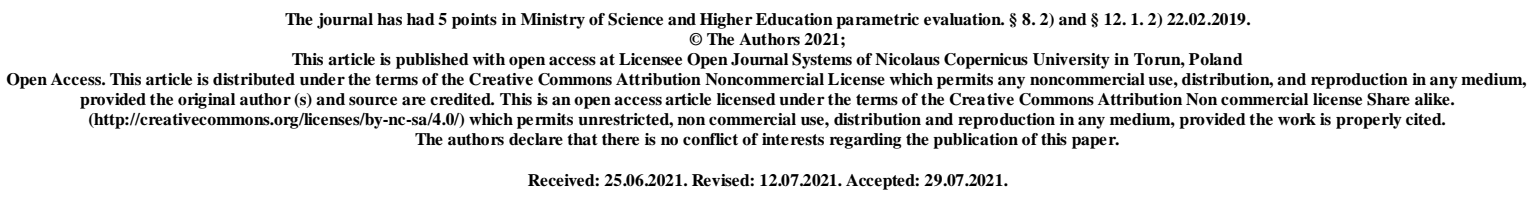

UDC: 616.34-008.6-06:616-056.527:575.113.2

\title{
THE ROLE OF ADIPOCYTOKINES AND ENDOTHELIAL DYSFUNCTION WITH IRRITABLE BOWEL SYNDROME ASSOCIATED WITH OBESITY
}

\author{
Yu. V. Bilooka, O. I. Fediv, H. Ya. Stupnytska, V. V. Bilookyi, O. V. Bilookyi, \\ Y. I. Rohovyi
}

Bukovinian State Medical University

Yuliia Bilooka- Postgraduate of department of internal medicine and infectious diseases of Bukovinian state medical university, Chernivtsi, Ukraine

O.I.Fediv- Chief of department of internal medicine and infectious diseases of Bukovinian state medical university, Chernivtsi, Ukraine

H.Ya. Stupnytska- Professor of department of propedeutics of internal diseases of Bukovinian state medical university, Chernivtsi, Ukraine

V.V. Bilookyi- Professor of department of surgery № 1 of Bukovinian state medical university, Chernivtsi, Ukraine

O.V. Bilookyi- Assistant of department of surgery № 1 of Bukovinian state medical university, Chernivtsi, Ukraine

Yurii Rohovyi-Chief of department of pathological physiology of Bukovinian state medical university, Chernivtsi, Ukraine.

\section{Abstract}

The article contains the analysis of results concerning investigation of adipocytokines content and endothelial dysfunction in 97 patients with irritable bowel syndrome associated with obesity.

The blood serum was examined for the content of adipocytokines (leptin, adiponectin, resistin), stable nitrogen monoxide metabolites (nitrites/nitrates), endothelin-1, intercellular adhesion molecule 1 (ICAM-1), and the number of circulating endothelial cells (CEC). 
Patients with IBS associated with obesity and prevailing diarrhea are found to develop a prominent imbalance of adipocytokines which is manifested in high levels of leptin and resisin and low level of adiponectin in the blood serum. Endothelial dysfunction evidenced by a high level of endothelin-1, the number of circulating endothelial cells, general NO and intercellular adhesion molecules 1, is characteristic for patients with IBS associated with obesity and prevailing diarrhea.

Key words: irritable bowel syndrome; obesity; adipocytokines; endothelial dysfunction.

Introduction. A continuous increase of irritable bowel syndrome (IBS) sickness rate is found in the developed countries and Ukraine as well $[1,2,3]$. Though IBS is of a benign course its long relapsing character results in reduced ability to work among those individuals able to work [4]. On the other hand, obesity is one of the most complicated medical-social issues today. The WHO experts estimate about 300 million of obese people in the world till 2025. In Ukraine approximately $30 \%$ of working people suffer from obesity, and every fourth resident has an excessive body weight [5]. In recent years scientists have been actively investigating the role of adipocytokines in pathogenesis of IBS [6].

Nitrogen oxide and mast cells are known to be involved into the development of IBS, though definite mechanisms of their role and interaction are not found [7].

Objective: to examine the content of adipocytokines in the blood serum and parameters of the endothelial functional state in patients with irritable bowel syndrome associated with obesity.

Materials and methods. 97 patients with IBS were involved into the study (37 men and 60 women aged from 22 to 56). The group of comparison included 10 individuals with obesity ( 7 women and 3 men aged from 25 to 44). The control group included 21 practically healthy individuals (PHI) (14 women and 7 men aged from 22 to 44). All the patients with IBS were divided into 4 groups depending on clinical syndrome (prevailing constipation or diarrhea) and concomitant obesity: IBS with prevailing diarrhea - I group (18 patients), II IBS with prevailing constipation (19 patients), III - IBS associated with obesity and prevailing diarrhea (30 patients), IV - IBS associated with obesity and prevailing constipation (30 patients).

The diagnosis of IBS was made according to the Rome criteria III (2006) Tand on the basis of clinical and instrumental methods of examination. Changes of stool consistency 
assessed according to the Bristol stool scale were taken as a determining sign of constipation or diarrhea [8].

The content of adipocytokines in the blood serum (leptin, adiponectin, resistin) was determined by means of the immunoassay method.

Endothelial functional state parameters were examined by the content of nitrogen monoxide stable metabolites (nitrites/nitrates) in the blood, endothelin-1 (ET-1), ICAM-1 content, and the number of circulating endothelial cells (CEC). The content of nitrogen monoxide stable metabolites (nitrites/nitrates) in the blood was examined by means of L.C. Green et al. method (1982), ET-1 level - by means of immunoassay using reagents produced by «Biomedica Medizinprodukte $\mathrm{GmbH}$ and $\mathrm{Co} \mathrm{KG}$ (Austria). ICAM-1 in the blood serum was examined by means of immunoassay using reagents manufactured by «Bender MedSystems» (Austria). The number of circulating endothelial cells (CEC) in the blood was determined by J. Hladovec method (1978) modified by N.N.Petryshchev et al. (1999).

The data obtained were mathematically processed by means of the computer programs BioStat 2009 Professional, version 5.8.4.3 (AnalystSoft Inc.), SPSS (Statistical Package for Social Science Statistics) 16.0, Statistica 10.0 StatSoft Inc., Microsoft Excel 2010. Dispersive analysis was applied to compare several groups. Differences were considered to be reliable with significance level $\mathrm{p}<0,05$.

Results and discussion. Analysis of adipocytokine content in the blood serum found that patients with IBS, associated obesity and prevailing diarrhea leptin level was the highest (5,8 times higher than that of the control, 2,2 times higher than in patients with IBS and prevailing diarrhea, and 4,4 times in patients with IBS and prevailing constipations) (Table1).

Comparison with the group of patients with obesity did not find any reliable difference. It should be noted that comparison of the patients suffering from IBS associated with obesity and prevailing constipations found this parameter to be $16,3 \%$ lower in the group. Leptin content in the blood serum of patients with IBS and prevailing diarrhea was 2,2 times higher than that of the control and 2,3 times higher in patients with obesity. It did not differ in patients with IBS and prevailing constipations from the level on PHI, and it was $50,2 \%$ lower than in patients from I group. In IV group of patients this parameter was 4,8 times higher than that of the control, but there was no reliable difference found concerning the group of comparison.

Analysis of the results of the examination concerning leptin level in the blood serum in patients with IBS is controversial. Thus, one of the studies indicates its low level in the blood serum in comparison with the control [9]. Another study found that blood serum leptin in 
patients with IBS and prevailing diarrhea did not differ reliably from that of the control group [10]. One more research found that leptin level in patients with IBS and prevailing diarrhea was reliably higher than in the group of patients without diarrhea and healthy individuals [11]. Leptin level and development of weakness with IBS are found to be associated [12]. Increase of adiponectin content in the blood serum of patients with IBS is indicated irrespective of the clinical syndrome, though statistically significant difference was found in the group of patients without diarrhea [11].

Table 1

Adipocytokines content in the blood serum of patients with irritable bowel syndrome associated with obesity

\begin{tabular}{|c|c|c|c|c|c|c|}
\hline Parameters & $\begin{array}{c}\text { PHI } \\
\text { (control) } \\
n=21\end{array}$ & $\begin{array}{c}\text { Obesity } \\
\text { (group of } \\
\text { comparison) } \\
n=10\end{array}$ & $\begin{array}{c}\text { IBS+ } \\
\text { diarrhea } \\
\text { (I group) } \\
\mathrm{n}=18\end{array}$ & $\begin{array}{c}\text { IBS }+ \\
\text { constipation } \\
\text { (II group) } \\
\mathrm{n}=19\end{array}$ & $\begin{array}{c}\text { IBS + } \\
\text { diarrhea } \\
\text { +obesity } \\
\text { (III group) } \\
\text { n=30 }\end{array}$ & $\begin{array}{c}\text { IBS + } \\
\text { constipation } \\
+ \\
\text { obesity (IV } \\
\text { group) } \\
\text { n=30 }\end{array}$ \\
\hline Leptin & $8,17 \pm 0,81$ & $\begin{array}{c}40,79 \pm 6,16 \\
p<0,05\end{array}$ & $\begin{array}{c}17,92 \pm 1,73 \\
\mathrm{p}<0,05 \\
\mathrm{p}_{1}<0,05\end{array}$ & $\begin{array}{c}8,93 \pm 1,06 \\
\mathrm{p}>0,05 \\
\mathrm{p}_{1}<0,05 \\
\mathrm{p}_{2}<0,05\end{array}$ & $\begin{array}{c}47,27 \pm 3,52 \\
\mathrm{p}<0,05 \\
\mathrm{p}_{1}>0,05 \\
\mathrm{p}_{2}<0,05 \\
\mathrm{p}_{3}<0,05\end{array}$ & $\begin{array}{c}39,57 \pm 2,31 \\
\mathrm{p}<0,05 \\
\mathrm{p}_{1}>0,05 \\
\mathrm{p}_{2}<0,05 \\
\mathrm{p}_{3}<0,05 \\
\mathrm{p}_{4}<0,05\end{array}$ \\
\hline Adiponectin & $7,71 \pm 0,57$ & $\begin{array}{c}3,88 \pm 0,30 \\
\mathrm{p}<0,05\end{array}$ & $\begin{array}{c}9,41 \pm 0,98 \\
\mathrm{p}>0,05 \\
\mathrm{p}_{1}<0,05\end{array}$ & $\begin{array}{c}10,10 \pm 0,69 \\
\mathrm{p}<0,05 \\
\mathrm{p}_{1}<0,05 \\
\mathrm{p}_{2}<0,05\end{array}$ & $\begin{array}{c}5,11 \pm 0,33 \\
\mathrm{p}<0,05 \\
\mathrm{p}_{1}>0,05 \\
\mathrm{p}_{2}<0,05 \\
\mathrm{p}_{3}<0,05\end{array}$ & $\begin{array}{c}4,34 \pm 0,26 \\
\mathrm{p}<0,05 \\
\mathrm{p}_{1}>0,05 \\
\mathrm{p}_{2}<0,05 \\
\mathrm{p}_{3}<0,05 \\
\mathrm{p}_{4}>0,05\end{array}$ \\
\hline Resistin & $5,10 \pm 0,24$ & $\begin{array}{c}11,45 \pm 0,92 \\
\mathrm{p}<0,05\end{array}$ & $\begin{array}{c}7,39 \pm 0,51 \\
\mathrm{p}>0,05 \\
\mathrm{p}_{1}<0,05\end{array}$ & $\begin{array}{c}6,14 \pm 0,41 \\
\mathrm{p}>0,05 \\
\mathrm{p}_{1}<0,05 \\
\mathrm{p}_{2}>0,05\end{array}$ & $\begin{array}{c}13,51 \pm 0,93 \\
\mathrm{p}<0,05 \\
\mathrm{p}_{1}>0,05 \\
\mathrm{p}_{2}<0,05 \\
\mathrm{p}_{3}<0,05\end{array}$ & $\begin{array}{c}12,41 \pm 0,79 \\
\mathrm{p}<0,05 \\
\mathrm{p}_{1}>0,05 \\
\mathrm{p}_{2}<0,05 \\
\mathrm{p}_{3}<0,05 \\
\mathrm{p}_{4}>0,05\end{array}$ \\
\hline
\end{tabular}

The results of our research are indicative of a higher level of adiponectin content in the blood serum in the group with obesity (twice as much) in comparison with the control group. It was found to be $31,0 \%$ higher in I group, 33,7\% - in II group, and in IV group - 1,8 times as much. In the group of patients with IBS and prevailing diarrhea this parameter did not differ reliably from that of PHI, but it was 2,4 times higher than that in the group of comparison. In the group of patients with IBS and prevailing constipations adiponectin level was 2,6 times higher in comparison with the group of patients with obesity and 7,3\% more 
than in the group of patients with IBS and prevailing diarrhea. In case of a comorbid course of IBS, obesity and prevailing diarrhea this parameter was 1,8 times higher than that of the patients with IBS and prevailing diarrhea, and it was twice as much when constipations prevailed. In the group of patients with IBS associated with obesity and prevailing constipations adiponectin content in the blood serum was 2,2 times less than in I group and 2,3 times - in II group. Reliable differences were not found between III and IV groups.

Resistin level in the blood serum appeared to be the highest in the group of patients with IBS, associated obesity and prevailing diarrhea (it was 2,6 times higher than that of the control, 1,8 times higher than in the group of patients with IBS and prevailing diarrhea, and 2,2 times higher than in II group. In the group of patients irrespective the prevailing clinical syndrome, the level of the parameter did not differ reliably from the control group, though concerning the group of comparison it was 1,5 times higher in I group and 1,9 times - in II group. In IV group of patients resistin content in the blood serum was 2,4 times higher than that of the control, 1,7 times - than the group of patients with IBS and prevailing diarrhea, and 2,0 times - with prevailing constipations. Reliable changes were not found in comparison with the group of patients suffering from IBS associated with obesity and prevailing diarrhea.

It should be noted that a comorbid course of IBS with obesity and prevailing clinical manifestation of diarrhea was characterized by a considerable imbalance of adipocytokines which was found in high levels of leptin and resistin with low content of adiponectin in the blood serum.

Recently endothelial dysfunction development has been confirmed in patients with IBS. Thus, one research admitted a high level of ET-1 with reduced parameters of nitrogen oxide with IBS and prevailing constipations [4].

Analysis of the endothelial functional state parameters found ET-1 level in the group of patients with IBS associated with obesity and prevailing diarrhea to be the highest $(1,5$ times higher than that of the control level, $13,1 \%$ more than in the group of comparison, $14,9 \%$ higher than in I group and 34,8 times higher than in II group) (Table 2). This parameter was higher than that of the control in other groups as well $(35,7 \%$ higher than in the group of comparison, in I group - 33,5\% higher, in III group - 13,8\% and in IV $-14,3 \%$ higher). In the group of patients suffering from IBS and prevailing constipations ET-1 level was 16,1\% higher than in the group with obesity and $14,8 \%$ lower than in the group of patients with IBS and prevailing diarrhea. In IV group it appeared to be $15,8 \%$ higher than in the group of comparison and $14.4 \%$ higher than in the group of patients with IBS and prevailing diarrhea. Comparison of III and IV groups of patients found that in the latter this parameter was $25,5 \%$ 
lower.

Table 2

Parameters of the endothelial functional state in patients with irritable bowel syndrome associated with obesity

\begin{tabular}{|c|c|c|c|c|c|c|}
\hline Parameters & $\begin{array}{c}\text { PHI } \\
\text { (control) } \\
n=21\end{array}$ & $\begin{array}{c}\text { Obesity } \\
\text { (group of } \\
\text { comparison) } \\
n=10\end{array}$ & $\begin{array}{c}\text { IBS+ } \\
\text { diarrhea } \\
\text { (I group) } \\
n=18\end{array}$ & $\begin{array}{c}\text { IBS }+ \\
\text { constipation } \\
\text { (II group) } \\
n=19\end{array}$ & $\begin{array}{c}\text { IBS + } \\
\text { diarrhea } \\
\text { +obesity } \\
\text { (III group) } \\
\text { n=30 }\end{array}$ & $\begin{array}{c}\text { IBS }+ \\
\text { constipation } \\
+ \\
\text { obesity (IV } \\
\text { group) } \\
\text { n=30 }\end{array}$ \\
\hline ET-1, & $14,40 \pm 0,17$ & $\begin{array}{c}19,54 \pm 0,34 \\
\mathrm{p}<0,05\end{array}$ & $\begin{array}{c}19,23 \pm 0,43 \\
\mathrm{p}<0,05 \\
\mathrm{p}_{1}>0,05\end{array}$ & $\begin{array}{c}16,39 \pm 0,41 \\
\mathrm{p}<0,05 \\
\mathrm{p}_{1}<0,05 \\
\mathrm{p}_{2}<0,05\end{array}$ & $\begin{array}{c}22,09 \pm 0,32 \\
\mathrm{p}<0,05 \\
\mathrm{p}_{1}<0,05 \\
\mathrm{p}_{2}<0,05 \\
\mathrm{p}_{3}<0,05\end{array}$ & $\begin{array}{c}16,46 \pm 0,42 \\
\mathrm{p}<0,05 \\
\mathrm{p}_{1}<0,05 \\
\mathrm{p}_{2}<0,05 \\
\mathrm{p}_{3}>0,05 \\
\mathrm{p}_{4}<0,05\end{array}$ \\
\hline 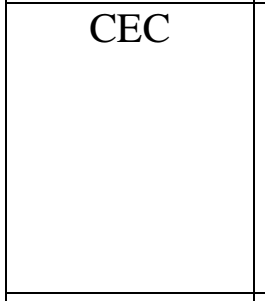 & $3,9 \pm 0,44$ & $\begin{array}{c}7,70 \pm 0,62 \\
\mathrm{p}<0,05\end{array}$ & $\begin{array}{c}12,26 \pm 0,99 \\
\mathrm{p}<0,05 \\
\mathrm{p}_{1}<0,05\end{array}$ & $\begin{array}{c}7,40 \pm 0,47 \\
\mathrm{p}<0,05 \\
\mathrm{p}_{1}>0,05 \\
\mathrm{p}_{2}<0,05\end{array}$ & $\begin{array}{c}19,93 \pm 0,82 \\
\mathrm{p}<0,05 \\
\mathrm{p}_{1}<0,05 \\
\mathrm{p}_{2}<0,05 \\
\mathrm{p}_{3}<0,05\end{array}$ & $\begin{array}{c}14,40 \pm 0,99 \\
\mathrm{p}<0,05 \\
\mathrm{p}_{1}<0,05 \\
\mathrm{p}_{2}>0,05 \\
\mathrm{p}_{3}<0,05 \\
\mathrm{p}_{4}<0,05\end{array}$ \\
\hline $\begin{array}{c}\text { Total nitrogen } \\
\text { oxide, } \\
\text { mcmol/L }\end{array}$ & $82,38 \pm 1,39$ & $\begin{array}{c}105,50 \pm 4,97 \\
\mathrm{p}<0,05\end{array}$ & $\begin{array}{c}131,21 \pm 3,27 \\
\mathrm{p}<0,05 \\
\mathrm{p}_{1}<0,05\end{array}$ & $\begin{array}{c}110,35 \pm 3,50 \\
\mathrm{p}<0,05 \\
\mathrm{p}_{1}>0,05 \\
\mathrm{p}_{2}<0,05\end{array}$ & $\begin{array}{c}150,33 \pm 5,25 \\
\mathrm{p}<0,05 \\
\mathrm{p}_{1}<0,05 \\
\mathrm{p}_{2}<0,05 \\
\mathrm{p}_{3}<0,05\end{array}$ & $\begin{array}{c}122,67 \pm 4,58 \\
\mathrm{p}<0,05 \\
\mathrm{p}_{1}>0,05 \\
\mathrm{p}_{2}>0,05 \\
\mathrm{p}_{3}>0,05 \\
\mathrm{p}_{4}<0,05\end{array}$ \\
\hline $\begin{array}{c}\text { Intercellular } \\
\text { adhesion } \\
\text { molecule } \\
\text { ICAM-1, } \\
\text { Un/ml }\end{array}$ & $249,77 \pm 1,25$ & $\begin{array}{c}262,68 \pm 4,40 \\
\mathrm{p}<0,05\end{array}$ & $\begin{array}{c}268,17 \pm 2,42 \\
\mathrm{p}<0,05 \\
\mathrm{p}_{1}>0,05\end{array}$ & $\begin{array}{c}260,30 \pm 2,57 \\
\mathrm{p}<0,05 \\
\mathrm{p}_{1}>0,05 \\
\mathrm{p}_{2}>0,05\end{array}$ & $\begin{array}{c}290,72 \pm 2,36 \\
\mathrm{p}<0,05 \\
\mathrm{p}_{1}<0,05 \\
\mathrm{p}_{2}<0,05 \\
\mathrm{p}_{3}<0,05\end{array}$ & $\begin{aligned} 265,63 \pm 3,33 \\
\mathrm{p}<0,05 \\
\mathrm{p}_{1}>0,05 \\
\mathrm{p}_{2}>0,05 \\
\mathrm{p}_{3}>0,05 \\
\mathrm{p}_{4}<0,05\end{aligned}$ \\
\hline
\end{tabular}

CEC appeared to be the highest in the group of patients with IBS associated with obesity and prevailing diarrhea (5,1 times higher than that of the control, 2,6 times - than the group of comparison, 1,6 times - than the group of patients with IBS and prevailing diarrhea, and 2,7 times - with prevailing constipations). This parameter was rather high in all the other groups of patients (twice as much in the group of comparison, 3,1 times - in I group, 1,9 times - in II group, 5,1 times - in III group and 3,7 times - in IV group). In the group of patients with IBS and prevailing diarrhea CEC was 1,6 times higher than in the group with obesity. In the group of patients with IBS and prevailing constipations it did not differ reliably from the group of comparison, but it was 1,7 times lower than in I group. In case of comorbid 
course of IBS, obesity and prevailing constipations CEC was 1,9 times higher than in the group of comparison and the group with IBS and prevailing constipations. It did not differ reliably from the group with IBS and prevailing diarrhea and it was 1,4 lower than in III group of patients.

The research carried out by S. An et al. determined nitrogen oxide participation in cytokine regulation with IBS including adipocytokines [7].

The content of the total nitrogen monoxide in comparison with the group of PHI was higher in all the groups of patients both in case of IBS associated with obesity irrespective of the clinical syndrome (1,8 times and 48,9\% respectively), and in case of comorbidity $(59,3 \%$ and $34,0 \%$ respectively), and in the group of patients with obesity $(28,1 \%$ higher). This parameter was $24.4 \%$ higher in I group of patients than in the group of comparison. In patients with IBS and prevailing constipations the level of the total nitrogen monoxide in the blood did not differ reliably from that in the group with obesity, but it was $18,9 \%$ higher than for prevailing diarrhea. In case of comorbid course of IBS with obesity and prevailing diarrhea the total nitrogen monoxide was the highest in comparison with other groups of patients $(42,3 \%$ - concerning the group of comparison, $14,6 \%$ - concerning I group, 36,2\% concerning II group and 22,5\% - concerning IV group).

The level of intercellular adhesion molecule (ICAM-1) in the blood appeared to be the highest in the group of patients with IBS associated with obesity and prevailing diarrhea (16,4\% higher than that of the control, $10,7 \%$ - than in the group of comparison, $8,4 \%$ - than in I group, $11,7 \%$ - than in II group and 9,4\% - than in IV group). In the group of patients with IBS irrespective of the clinical syndrome this parameter was $7,4 \%$ and $4,2 \%$ higher than in PHI respectively, but it did not differ reliably from the group of comparison and between themselves. In the group of patients with IBS associated with obesity and prevailing constipations the level of intercellular adhesion molecule (ICAM-1) was 6,3\% higher than that of the control.

Therefore, we have found in our research that the most considerable changes of the endothelial functional state (a high content of ET-1, CEC, total nitrogen monoxide, and intercellular adhesion molecule ICAM-1) were registered in patients with IBS associated with obesity and prevailing diarrhea as clinical manifestation.

Our study resulted in the assumption that endothelial dysfunction occurring due to comorbid course of IBS and obesity influences upon the level of adipocytokines, and leptin level in particular, which plays a certain role in the development of IBS. Reliably more considerable changes of the endothelial functional state and therefore more substantial 
imbalance of adipocytokines are found in case of diarrhea prevailing in clinical manifestation. It might be associated with more pronounced inflammatory processes in the intestinal wall and therefore development of systemic inflammation in case of IBS with prevailing diarrhea.

Conclusions. Patients with IBS associated with obesity and prevailing diarrhea are found to develop a prominent imbalance of adipocytokines which is manifested in high levels of leptin and resisin and low level of adiponectin in the blood serum. Endothelial dysfunction evidenced by a high level of endotelin-1, the number of circulating endothelial cells, general NO and intercellular adhesion molecules 1, is characteristic for patients with IBS associated with obesity and prevailing diarrhea.

\section{References}

1. Chey WD, Kurlander J, Eswaran S. Irritable bowel syndrome: a clinical review. JAMA. 2015 Mar 3;313(9):949-58.

2. Defrees DN, Bailey J. Irritable Bowel Syndrome: Epidemiology, Pathophysiology, Diagnosis, and Treatment. Prim Care. 2017 Dec;44(4):655-671.

3. Ford AC, Lacy BE, Talley NJ. Irritable Bowel Syndrome. N Engl J Med. 2017 Jun 29;376(26):2566-2578.

4. Gridnieva S, Reznichenko O, Martynenko M. Irritable bowel syndrome with constipation: issues of pathogenesis, diagnostics and treatment. Actual problems of modern medicine. 2020; 6: 4-11.

5. Dereń K, Nyankovskyy S, Nyankovska O, Łuszczki E, Wyszyńska J, Sobolewski M, Mazur A. The prevalence of underweight, overweight and obesity in children and adolescents from Ukraine. Sci Rep. 2018 Feb 26;8(1):3625.

6. Kristen $\mathrm{R}$ Weaver, Christina M Boulineaux, Jeffrey M Robinson, Kierra Butler, Margaret M Heitkemper, Wendy A Henderson. Sex Hormones, BDNF, Leptin, and TGF- $\beta 1$ in Females With IBS: A Pilot InvestigationBiol Res Nurs 2021 Apr;23(2):231-237.

7. An S, Zong G, Wang Z, Shi J, Du H, Hu J. Expression of inducible nitric oxide synthase in mast cells contributes to the regulation of inflammatory cytokines in irritable bowel syndrome with diarrheaNeurogastroenterol Motil 2016 Jul;28(7):1083-93.

8. Ford AC, Bercik P, Morgan DG. [et al.] Validation of the Rome III criteria for the diagnosis of irritable bowel syndrome in secondary care. Gastroenterology. 2013; 145(6): 1262-1270.

9. Roshandel SS, Keshtkar G. Serum Leptin Levels and Irritable Bowel Syndrome: A New Hypothesis. Journal of Clinical Gastroenterology. 2009; 43(9): 826-830. 
10. Liu De-Rong, Xu Xiao-Juan, Yao Shu-Kun. Increased intestinal mucosal leptin levels in patients with diarrhea-predominant irritable bowel syndrome. World $\mathbf{J}$ Gastroenterol. 2018; 24(1): 46-57.

11. Russo F, Chimienti G, Riezzo G., Linsalata M, D'Attoma B, Clemente C, Orlando A. Adipose Tissue-Derived Biomarkers of Intestinal Barrier Functions for the Characterization of Diarrhoea-Predominant IBS. Dis Markers. 2018; 2018: 1827937. Published online 2018 Nov 28. doi: 10.1155/2018/1827937.

12. Thierry P, Pierre-Michel H, Eve G, Mariné BE, Faredj C, Xavier C-BF, Xavier H, Alber T. Fatigue in irritable bowel syndrome: characterization and putative role of leptin European Journal of Gastroenterology \& Hepatology. 2007; 19(3): 237-243. 